\title{
Change in photosynthetic pigments of Date palm offshoots under abiotic stress factors
}

\author{
Hussein J. Shareef ${ }^{*}$, Gholamreza Abdi², Shah Fahad ${ }^{3}$ \\ ${ }^{1}$ Department of Date Palm Research Center, University of Basrah, Basrah, Iraq \\ ${ }^{2}$ Department of Biotechnology, Persian Gulf Research Institute, Persian Gulf University, Bushehr, 7516913817, \\ Iran \\ ${ }^{3}$ National Key Laboratory of Crop Genetic Improvement, MOA Key Laboratory of Crop Ecophysiology and \\ Farming System, College of Plant Science and Technology, Huazhong Agricultural University, Wuhan, China
}

\begin{abstract}
ShareEF, H.J., AbDi, G., FAHAD, S., 2020. Change in photosynthetic pigments of Date palm offshoots under abiotic stress factors. Folia Oecologica, 47 (1): 45-51.

Increasing world temperatures are bringing about climate changes creating abiotic stress in plants. Date palm offshoot leaves (Khadrawi cv.) were analyzed for chlorophyll Chl $a$, Chl $b$, Total Chl, Chl $a / b$ ratio, anthocyanin and carotenoid subject to salinity, drought and temperature stress under field conditions. Results demonstrated that drought and salinity stress accompanied by high temperatures in July and August significantly reduced the $\mathrm{Chl} a, \mathrm{Chl} b$, and Total $\mathrm{Chl}$ relative to the control. Anthocyanins, carotenoids, hydrogen peroxide, and malondialdehyde were markedly higher in July and August $\left(45^{\circ} \mathrm{C}\right)$, whereas September showed lower values in these substances. Temperature reduction to $35^{\circ} \mathrm{C}$ accompanied by drought or salinity stress, brought about a critical increment in relative water content and a decrease in electrolyte leakage. Although the impact of drought and salinity stress continued, the reduced temperatures in September resulted in a reduction of abscisic acid and proline concentration. Cluster analysis showed the two groups. In this first group, the significant similarity between the treatments is illustrated by the influence of the high temperature of 43-45 ${ }^{\circ} \mathrm{C}$. Recovery of photosynthesis following low-temperature, for the most part, determines plant flexibility to water deficiencies and salinity. Thermal stress, associated with salinity or drought stress is more damaging to the photosynthetic pigments than any single factor.
\end{abstract}

Keywords

antioxidative mechanism, electrolyte leakage, lipid peroxidation, Phoenix dactylifera L.

\section{Introduction}

The increase in world temperatures is bringing about climate change resulting in significantly higher abiotic stresses in crop plants (MATHUR et al., 2014. The recurrence and duration of such abiotic stresses will soon be intensified with the warming of the global climate and its impact on annual crop plants in critical periods of growth (LAMAOUI et al., 2018).

Together, salinity, drought, and heat stress commonly account for a decline in photosynthetic pigment substances, especially chlorophyll. This reduction occurs because of stress-initiated alterations in pigment synthesis or pigment degradation. Further, the degree of those phenomena depends on the species, type of stress, duration of the stress period, and resilience to the stresses (WATKINS et al., 2017). Anthocyanin assumes an essential function in protecting plants through scavenging receptive ROS (URBAN et al., 2017). Likewise, carotenoids are critical for the photoprotection of photosynthesis and plants experienc-

*Corresponding author:

e-mail: husseinshareef@live.com 
ing abiotic/biotic stress (PANDEY et al., 2017). Moreover, understanding the biosynthesis/degradation of photosynthetic pigments is, in fact, at the center of the plant stress tolerance mechanism underlying abiotic stress factors (AL OMRON et al., 2012).

Under field conditions, abiotic stress conditions like drought and salinity infrequently happen in separation, and the course of many stress burdens is usually not predictable through single-factor examinations on account of synergistic, threatening, or, on the other hand, masking impacts which can occur (RAstogi et al., 2019). An instance of an opposite reaction to stresses is the perception that the constant temperature of photosynthesis can capture water, focusing on the plant leaves, in contrast with wetter conditions, indicating that one factor may shape another (CHAVES et al., 2012). The high temperature disrupts the synthesis of photosynthetic pigments, damages the chloroplast membranes, and lowers chlorophyll and other pigments. As well as increase the abscisic acid in controlling closure of stomata, compatible osmolyte, and the evolution of genes of an adaptation response (ZANDALINAS et al., 2016). In this case, the stomata prepare the $\mathrm{CO}_{2}$ pathway to stabilize the carbon photosynthesis. And stomata prevent further water loss through the transpiration process to maintain the leaf temperature (REYNOLDSHenn et al., 2010).

Date palm (Phoenix dactylifera L.) is the third most essential palm species in world agricultural industries, after coconut and African oil palm. Date palms are subjected to various abiotic stress factors in southern Iraq, such as salinity, drought, and heat; the palms try to regulate their growth and developmental processes to reduce the magnitude of injury caused by the environmental burden (SHAREEF, 2019). These changes are typically transient and reversible, and their induction level is determined by the exposure time to a particular ecological factor (ABBAS et al., 2015). Furthermore, Date palm offshoot growth decreases from May to September as a result of the abnormal state of salinity, water scarcity, and high temperatures $\left(\mathrm{J}_{\mathrm{A}}-\right.$ sim et al., 2016).

Most abiotic stress studies are performed under controlled conditions inside a research facility and do not duplicate the specific requirements found in the field. An impressive gap exists between the data generated from laboratory and greenhouse experiments, and the data required to create plants with expanded resilience of yields under field conditions (PereIRA, 2016). In particular, the chance to measure the responses of the plant stress in vivo is becoming increasingly important. In this study, we investigated photosynthetic pigment parameters as indicators in plants subjected to abiotic stress to determine the critical period in the summer season, plant responses and recovery ability to changes of temperature, which accompanies the salinity and drought stress factors.

\section{Materials and methods}

\section{Research site and development conditions}

Field analysis was performed at a private date plantation in the Alhartha region, Basrah, Iraq $\left(30^{\circ} 37^{\prime} 52.68^{\prime \prime} \mathrm{N}\right.$ and $47^{\circ} 45^{\prime} 8.15^{\prime \prime} \mathrm{E}$ ), two growing seasons. Twenty uniform date palms, girth $\pm 10 \mathrm{~cm}$, vigorous 3-4-year-old 'Khadrawi' offshoots were used in the experiment. The selected offshoots were planted at $5 \times 5 \mathrm{~m}$ spacing in silty clay loam soil. Regular soil EC was $4 \mathrm{dS} \mathrm{m}^{-1}$, just as the normal EC water $5 \mathrm{dS} \mathrm{m}^{-1}$, then drip irrigation followed for all treatments. In the first season, 15 May 2017 to 15 May 2018, each treatment was replicated five times. Each plant was treated with Control irrigated $75 \%$ field capacity $\left(120 \mathrm{ml}\right.$ depth of water) without saltwater $0 \mathrm{dS} \mathrm{m} \mathrm{m}^{-1}$, for the drought treatment, the offshoots irrigated without saltwater $0 \mathrm{dS} \mathrm{m}^{-1}$ with $25 \%$ field capacity $(40 \mathrm{ml}$ depth of water), for salinity treatment irrigated $75 \%$ field capacity with salt water $5 \mathrm{dS} \mathrm{m}^{-1}$, all these treatments subjected to the field temperature. The average temperature of the field area was in May $37^{\circ} \mathrm{C}$, June $40^{\circ} \mathrm{C}$, July $43^{\circ} \mathrm{C}$, August $45^{\circ} \mathrm{C}$, and September $35^{\circ} \mathrm{C}$. These averages were measured by hygro-thermometer at $1,100 \mathrm{~h}$ daily, to record the correct air temperature in circulation. There was no rainfall in the months of the experiments.

After one year of treatments, the same procedures were continued in the second season (15 May to 15 September 2018); the following data were recorded on day 15 of each month:

\section{Parameters of the experiment}

Pigment contents were extracted according to LICHTENTHALER and WeLlbURN (1983). Hydrogen peroxide $\left(\mathrm{H}_{2} \mathrm{O}_{2}\right)$ accumulation in date palm leaves determined following SERGIEv et al. (1997). Lipid peroxidation constrained by assessing the proportion of Malondialdehyde (MDA) arrangement using the thiobarbituric acid system after STEWART and BEWLEY (1980). Film strength was evaluated by estimating the conductivity of leachates contained in the harmed plasma layer following the strategy of SHANAHAN et al. (1990). In the proline focus, $0.5 \mathrm{~g}$ of dry leaves was homogenized with $5 \mathrm{ml}$ of $95 \%$ ethanol, according to IRIGOYEN et al. (1992).

Extraction, purification, and quantitative assurance of free and bound abscisic acid were done, with minor changes, following the techniques of TANG et al., 2011. Leaf samples were weighed (fresh biomass) promptly after collection and soaked in distilled water at $25^{\circ} \mathrm{C}$ for $24 \mathrm{~h}$, to estimate the RWC, according to JASIM et al. (2016).

\section{Statistical analyses}

Randomized completely block design of abiotic stress factors replicated five times were used in the experiment. Test information on all factors exposed to the investigation of fluctuation (ANOVA) systems utilized, a Tukey's correction for multiple comparisons treatments considered at the $\mathrm{P} \leq 0.05$ levels. The cluster analysis was performed using IBM SPSS (Ver. 23.0), targetting the attributes measured in the leaves with distances as similarity measures were applied to analyze the effect of treatments on photosynthetic pigments and biochemical parameters. 


\section{Results}

\section{Changes in photosynthesis pigments under abiotic stress}

Data regarding Chl $a, b$, total Chl, Chl $a / b$ ratio, anthocyanin, and carotenoid are presented in Figs 1-2,a-b. It is demonstrated that the drought and salinity stress accompanied by high field temperature in July $\left(43{ }^{\circ} \mathrm{C}\right)$ and August $\left(45^{\circ} \mathrm{C}\right)$ significantly reduced the $\mathrm{Chl} a, b$, and total Chl compared with the control, whereas anthocyanins and carotenoids increased considerably. In September (37 $\left.{ }^{\circ} \mathrm{C}\right) \mathrm{Chl} a, b$, total $\mathrm{Chl}$, Chl $a / b$ ratio increased whereas anthocyanin and carotenoids significantly decreased. The higher temperature of the field in August $\left(45^{\circ} \mathrm{C}\right)$ recorded a considerably higher $\mathrm{Chl} a / b$ ratio, whether under stress (drought and salinity) or without stress. In September, the Chl $a / b$ ratio decreased except under drought stress (Fig. 1d). The decrease in Chl $b$ was very sharp in August, which brought about a higher $\mathrm{Chl} a / b$ proportion as the field temperatures peaked. The reduction of chlorophyll pigments was higher under salt stress than under drought stress (Fig. 1c).

\section{Changes in the chemical response under abiotic stress}

The salinity and drought treatments significantly increased electrolyte leakage, proline concentration, hydrogen peroxide, MDA, and ABA (Figs 2-3) in July and August, during both months; the average temperature remained between $43-45^{\circ} \mathrm{C}$, whereas the RWC decreased (Fig. 3d). These results are striking as a result of high air temperature causing a significant decrease in membrane stability using electrolyte leakage as index and RWC of all treatments to include freshwater, drought and salinity-treated plants (Fig. 3a-d). In contrast, reducing the temperature to $\left(37^{\circ} \mathrm{C}\right)$ in September, accompanied by both drought and salinity stress, resulting in a significant increase in membrane stability and RWC. Although the impact of drought and salinity stress continued, the reduction in temperature in September resulted in a decrease of $\mathrm{ABA}$ and proline concentration (Fig. 2d). In contrast, ABA content in September was higher than May under drought stress (Fig. $3 c)$. The production of $\mathrm{H}_{2} \mathrm{O}_{2}$ was lower in control in comparison to salt and drought treatments (Fig. 2c).

\section{Cluster analysis of abiotic stress treatments}

Hierarchical cluster analysis was carried out of abiotic factors represented by all 15 treatments and their effects on the photosynthesis pigments ( $\mathrm{Chl} a, b$, total $\mathrm{Chl}, \mathrm{Chl} a / b$ ratio, anthocyanin, and carotenoid) of the leaf noted (Fig. 4 ). The cluster analysis showed two distinct clusters. The first group included drought, salinity, and control treatments in July and August (July-S, Aug-D, Aug-S, July$\mathrm{D}$, Aug-C). In this first group, the significant similarity between the treatments is illustrated by the influence of the high temperature of $43-45^{\circ} \mathrm{C}$ while the second group included drought, salinity, and control treatments in May, June, and September (May-C, Sept-C, June-D, June-S, May-D, June-C, May-S, Sept-S, Sept-D), which showed the effect of low temperatures $\left(37-40-35^{\circ} \mathrm{C}\right)$ on improved plant growth, except for the control in July (July-C).

Hierarchical cluster analysis of all parameters (pigments contents, hydrogen peroxide, malondialdehyde, electrolyte leakage, proline, ABA, and leaf RWC) affected by abiotic stress (Fig. 5) showed two distinct clusters. The second group included drought, salinity, and control treatments in May, June, and September (May-C, Sept-C, May$\mathrm{D}$, June-C, May-S), the significant similarity between the treatments is illustrated by the influence of the low temperature of $\left(37-40-35^{\circ} \mathrm{C}\right)$ on improved plant growth while the first group included drought, salinity, and control treatments in May, June, and September (June-D, July-C, SeptS, June-S, July-D, Aug-C, Aug-D, Aug-S, July-S, SeptD), which showed the interaction of high temperatures $\left(43-45^{\circ} \mathrm{C}\right)$ with drought and salinity on decreased plant growth.

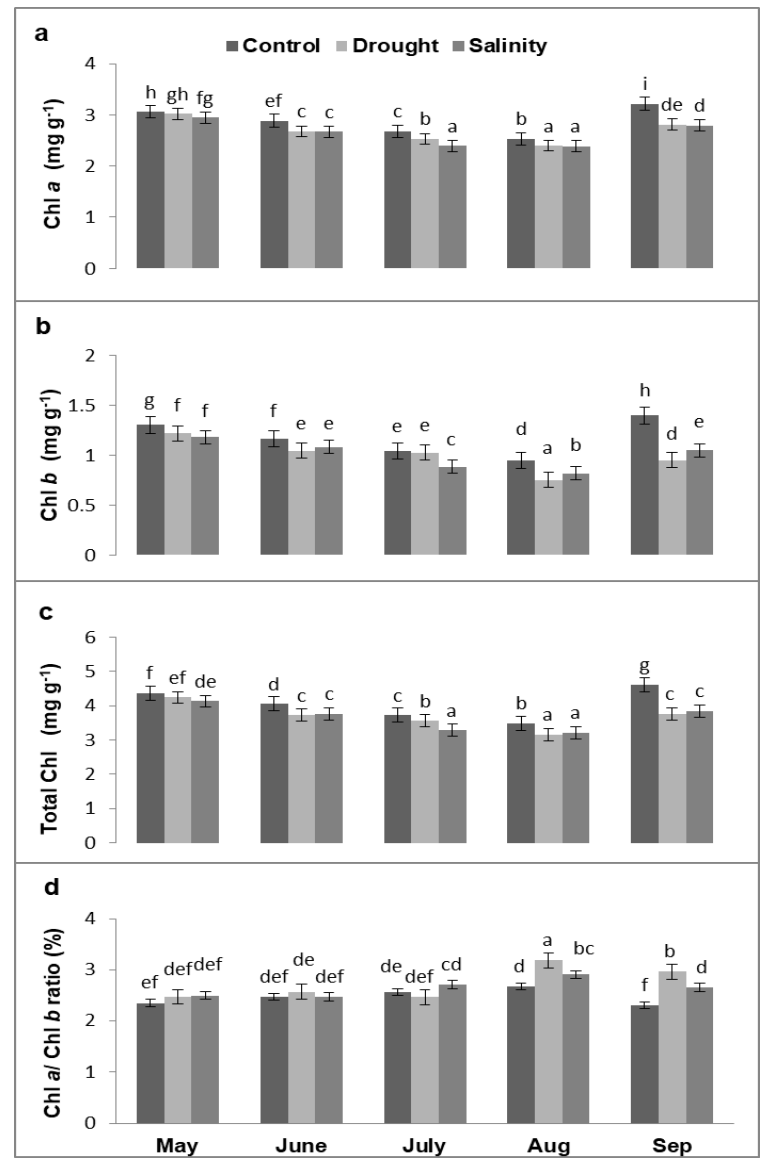

Fig. 1. Changes in Chl $a$ (a), Chl $b$ (b), total Chl (c), and Chl $a / \mathrm{Chl} b$ ratio (d) of Date palm offshoots leaves under different abiotic stresses. Results are means $\pm \mathrm{SD}(\mathrm{n}=5)$. The same letters are not significantly different $\mathrm{p} \leq 0.05$ after Tukey's correction for multiple comparisons. 

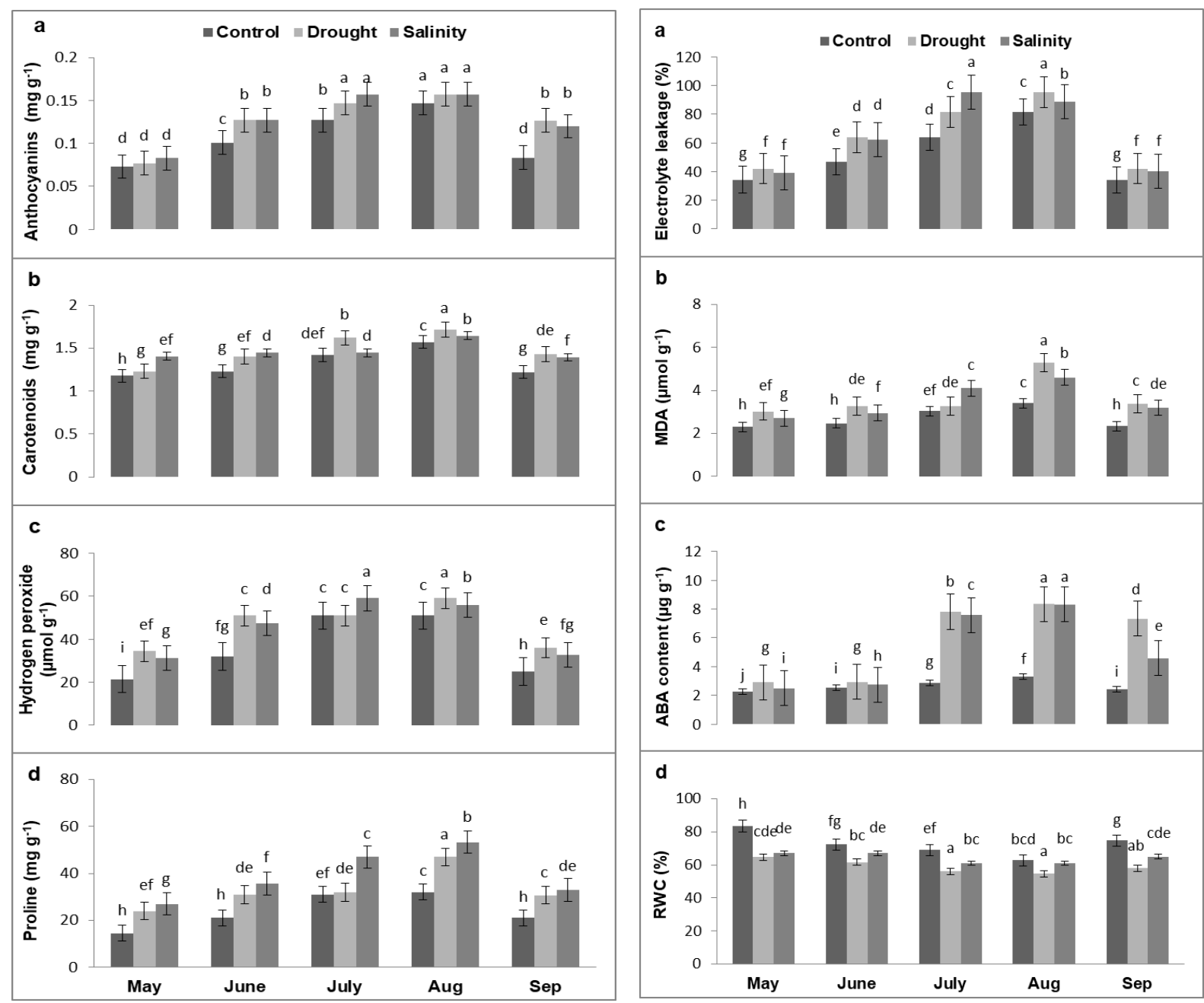

Fig. 2. Changes in anthocyanins (a), carotenoids (b), hydrogen peroxide (c), and proline concentration (d) of Date palm offshoots leaves under different abiotic stresses. Results are means $\pm \operatorname{SD}(n=5)$. The same letters are not significantly different $\mathrm{p} \leq 0.05$ after Tukey's correction for multiple comparisons.

\section{Discussion}

One of the pressing issues arising in some areas of Date palm offshoot cultivation is different levels of injuries caused by salinity, drought and high temperatures in the summer season, which is a combination of these factors of abiotic stresses. Hence, we hypothesize that date palms with high-stress tolerance have a high capacity to change photosynthesis pigments because of abiotic stress, such as high temperature. By targeting chlorophyll, anthocyanin and carotenoid to identify abiotic stress responses in Date palm offshoots, we focused on different factors of abiotic stress such as salinity and drought under the various temperature conditions of May, June, July, August, and September.

Reduction in pigment content may be a direct result of the prohibitive consequence of the aggregated particles of various salts on the biogenesis of the different pigment portions (SHAH et al., 2017). Chlorophyll pigments de-

Fig. 3. Changes in electrolyte leakage (a), MDA (b), ABA content (c), and RWC (d) of Date palm offshoots leaves under different abiotic stresses. Results are means \pm SD $(\mathrm{n}=5)$. The same letters are not significantly different $\mathrm{p} \leq 0.05$ after Tukey's correction for multiple comparisons.

pending on the factor of abiotic treatments, and the high temperature in the field reduced. Concerning drought stress treatment and water scarcity, they cause pigment degradation and membrane damage (Figs 1-3a). Salt stress causes decreased leaf water potential, and the RWC was thereby affected by overall photosynthetic capacity (HNILIČKoví et al., 2017). However, anthocyanin or carotenoid accumulation may facilitate the protection of chemical process mechanisms by screening them from the hazardous impacts of pressure producing superoxide radicals, while not constraining photosynthesis. Anthocyanins are thought to limit oxidative harm and act as antioxidants by neutralizing ROS directly (Fondom et al., 2009). However, the high air temperature reveals significant impacts on plant metabolism - that affect the generation and aggregation of auxiliary plant mixes, for example, a carotenoid which is layer bound exacerbates fundamental capacities in photosynthesis (XU et al., 2015). Heat stress arises from high temperatures that lead to damage plant tissue; tem- 
Distance

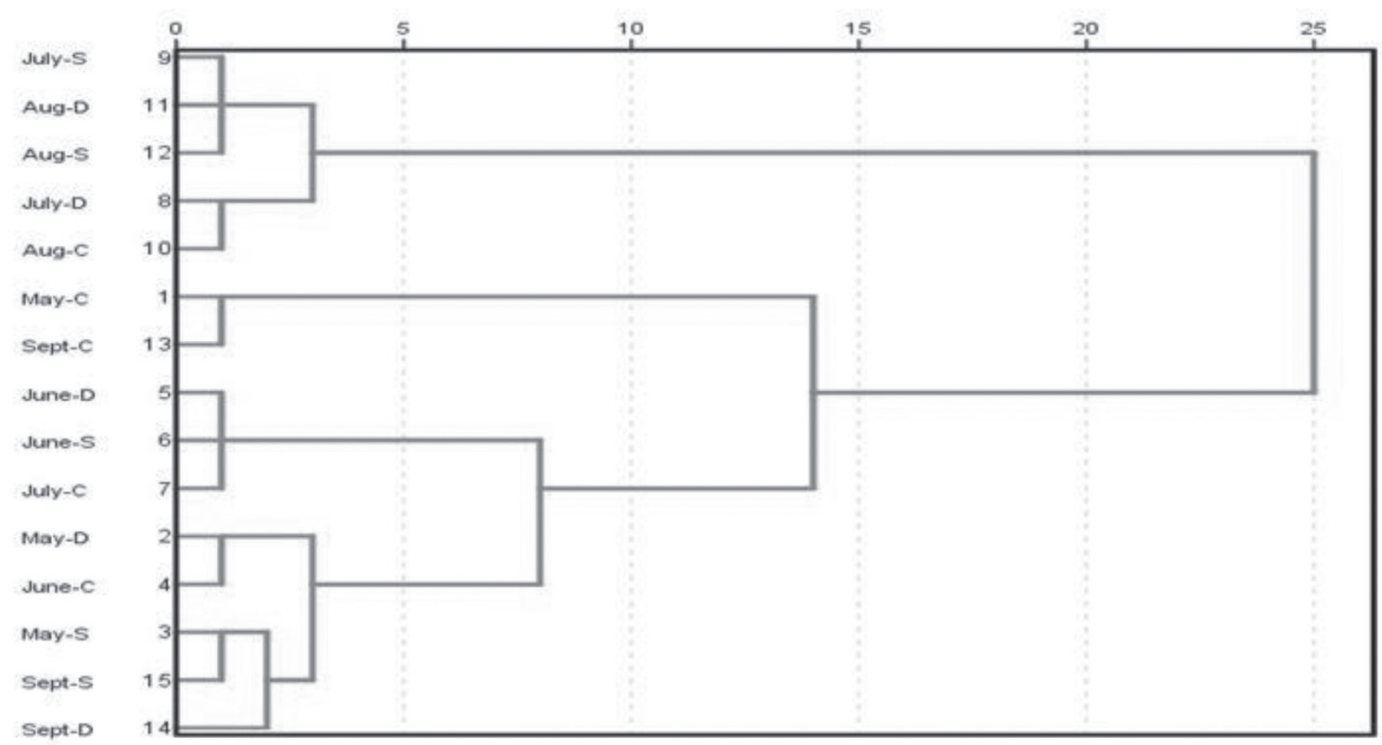

Fig. 4. Dendrogram of hierarchical clustering to leaves of Date palm offshoot under different abiotic stress by using photosynthesis pigments as an indicator.

\section{Distance}

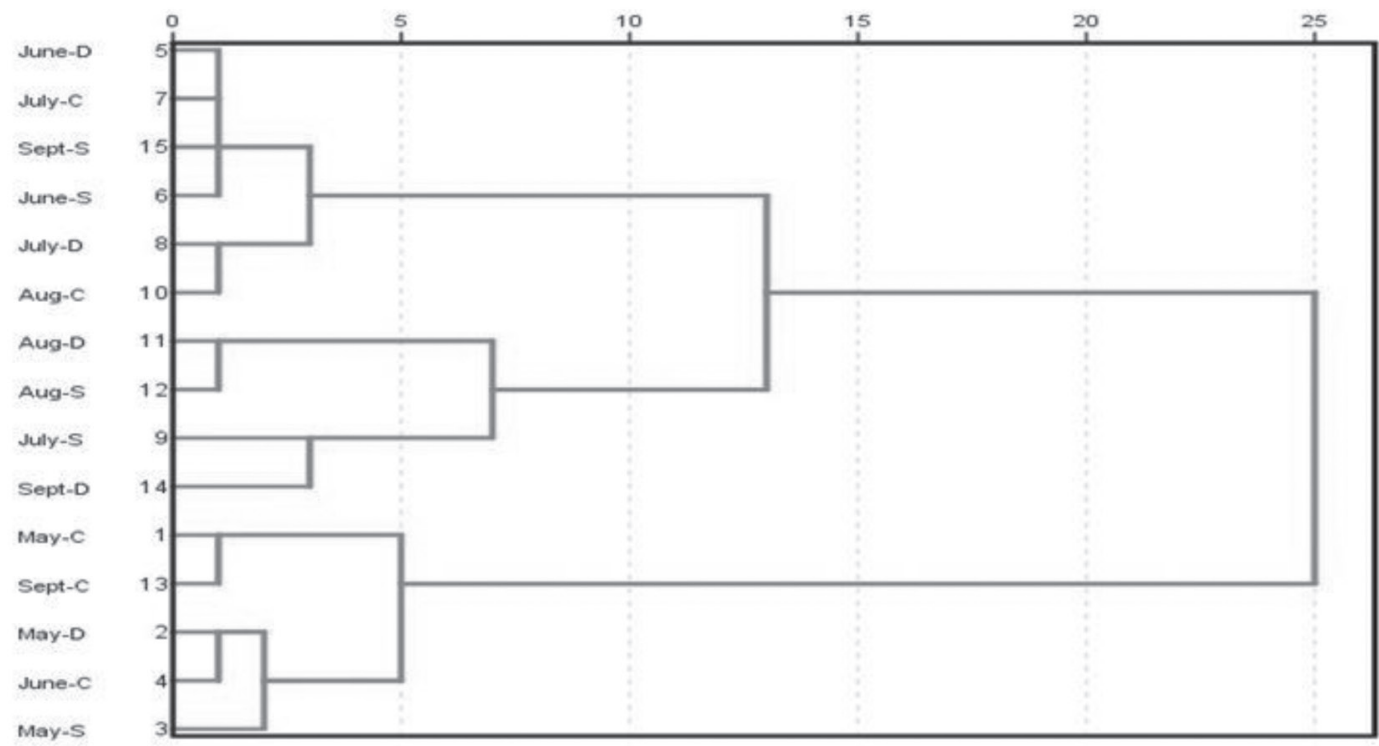

Fig. 5. Dendrogram of hierarchical clustering to leaves of date palm offshoot under different abiotic stress by use (pigments contents, hydrogen peroxide, malondialdehyde, electrolyte leakage, proline, ABA, and leaf RWC) as an indicator.

peratures in the degree of $35-45^{\circ} \mathrm{C}$ in the tropics affect the different plant species (NIEvola et al., 2017).

Chemical responses to abiotic stress may lead to conditions of a superior level of assurance against oxidative harm in the control treatment by quick evacuation of $\mathrm{H}_{2} \mathrm{O}_{2}$ or by other scavenging frameworks. $\mathrm{H}_{2} \mathrm{O}_{2}$ was lower under drought than salt in the case of the high temperature of the field, which implies that the generation of $\mathrm{H}_{2} \mathrm{O}_{2}$ decreased by the antioxidative actions of the plant. Under salinity, $\mathrm{H}_{2} \mathrm{O}_{2}$ content increased at higher temperatures (Fig. 2c).
The electrolyte leakage through plasmalemma is associated with the activity of photosynthetic and mitochondrial reactions (ShalabY, 2018). The increase in $\mathrm{H}_{2} \mathrm{O}_{2}$ content in the present analysis initiated malondialdehyde (MDA) (Fig. 3b). The harmful impact of ROS is the lipid peroxidation anticipated by the formation of MDA (AYALA et al., 2014). MDA significantly increased upon water deprivation, as the field temperature increased (Fig. 2b). Generally, under typical conditions, the generation and expulsion of ROS are in a balanced state (Sсноотs et al., 2018). 
Proline accumulation in response to stress supplies vitality for advancement and survival, and in this manner, allows the plant to endure stress (JASIM et al., 2016). The ABA has an impact on some pathways unmistakable from the acceptance of HSPs (HSP qualities deciphered in all eukaryotes through a similar procedure). Specific saved interpretation factors, called HSFs, perceive and tie to rationed cis components (the HSE) in the advertiser of HSP and different qualities (Nover et al., 2001). ABA content in September was higher than May under drought stress (Fig. 2c). ABA-prompted stomata closure mostly dependent on NADPH oxidase action (WATKINS et al., 2017). Our outcomes revealed that RWC decreased more with drought stress than salt stress conditions (Fig. 3d), indicating that plants were under stress at the time of sampling. Among every one of the treatments examined, the imposition of salt and drought treatments resulted in a critical decline in RWC of those offshoots which developed under field conditions.

Cluster analysis showed the convergence of the effect of salt, drought stress, and control in the impact on the date palms under low temperature while distinguishing the effect of low and high temperature in the photosynthetic pigments and biochemical parameters. Similarities in the results were obtained with a study of HAIDER et al. (2015) on the effect of environmental differences on Date palm varieties. The difference in temperature affecting the content of photosynthesis pigments in the leaves indicates that high temperature is the determining factor for plant growth and the most influential in plant development.

\section{Conclusions}

Photosynthesis pigments are a fundamental indicator of the effect of various abiotic stress factors on plants. Periods of stress that occur commonly during the two hottest months of the summer season indicated that high temperature is the primary factor that determines the growth of plants. Recovery of photosynthesis following low-temperature alleviation, for the most part, determines the plant flexibility to water deficiencies and salinity. Consequently, our study represents an initial contribution to understanding the physiological events occurring during the critical period of date palm offshoot growth throughout the summer season.

\section{Acknowledgements}

Authors are grateful to Professor Dennis V. Johnson of Cincinnati, Ohio, USA, for critical review and editorial enhancement of this manuscript. This work is part of the scientific plan of the Date Palm Research Center, University of Basrah.

\section{References}

Abbas, M.F., Jasim, A.M., Shareef, H.J., 2015. Role of sulphur in salinity tolerance of Date palm (Phoenix dacty- lifera L.) offshoots cvs. Berhi and Sayer. International Journal of Agricultural and Food Science, 5: 92-97.

Al Omron, A.M., El-Maghraby, S.E., Nadeem, M.E.A., ElEter, A.M., Al-Mohani, H., 2012. Long term effect of irrigation with the treated sewage effluent on some soil properties of Al-Hassa Governorate, Saudi Arabia. Journal of the Saudi Society of Agricultural Sciences, 11: 1518. https://doi.org/10.1016/j.jssas.2011.04.004

Ayala, A., Muñoz, M.F., Argüelles, S., 2014. Lipid peroxidation: production, metabolism, and signaling mechanisms of malondialdehyde and 4-hydroxy-2-nonenal. Oxidative Medicine and Cellular Longevity, 2014: 1-31. https://doi.org/10.1155/2014/360438

Chaves, M.M., Zarrouk, O., Francisco, R., Costa, J.M., Santos, T., Regalado, A.P., Rodrigues, M.L., Lopes, C. M., 2012. Grapevine under deficit irrigation: Hints from physiological and molecular data. Annals of Botany, 105: 661-676.

Fondom, N.Y., Castro-Nava, S., Huerta, A.J., 2009. Photoprotective mechanisms during leaf ontogeny: cuticular development and anthocyanin deposition in two morphs of Agave striata that differ in leaf coloration. BotanyBotanique, 87: 1186-1197.

Haider, M.S., Khan, I.A., Jaskani, M.J., Naqvi, S.A., HaMEED, M., AZAM, M., PinTAud, J.C., 2015. Assessment of morphological attributes of Date palm accessions of diverse agro-ecological origin. Pakistan Journal of Botany, 47: 1143-1151.

HniličKová, H., HniličKa, F., Martinková, J., Kraus, K., 2017. Effects of salt stress on water status, photosynthesis and chlorophyll fluorescence of rocket. Plant, Soil and Environment, 63: 362-367. https://oi. org/10.17221/398/2017-PSE

IrigoYen, J.J., Emerich, D.W., SANChez-Diaz, M., 1992. Water stress induced changes in concentrations of proline and total soluble sugars in nodulated alfalfa (Medicago sativa) plants. Physiologia Plantarum, 84 (1): 55-60.

Jasim, A.M., AbBas, M.F., Shareef, H.J., 2016. Calcium application mitigates salt stress in Date palm (Phoenix dactylifera L.) offshoots cultivars of Berhi and Sayer. Acta Agriculturae Slovenica, 107: 103-112. https://doi. org/10.14720/aas.2016.107.1.11

Lamaoui, M., Jemo, M., Datla, R., Bekkaoui, F., 2018. Heat and drought stresses in crops and approaches for their mitigation. Frontiers in Chemistry, 6: 1-14. https://doi. org/10.3389/fchem.2018.00026

Lichtenthaler, H.K., Wellburn, A.R., 1983. Determinations of total carotenoids and chlorophylls a and b of leaf extracts in different solvents. Biochemical Society Transactions, 11: 591-592.

Mathur, S., Agrawal, D., Jajoo, A., 2014. Photosynthesis: response to high temperature stress. Journal of Photochemistry and Photobiology B: Biology, 137: 116-126. https://doi.org/10.1016/j.jphotobiol.2014.01.010

Nievola, C.C., Carvalho, C.P., Carvalho, V., Rodrigues, E., 2017. Rapid responses of plants to temperature changes. Temperature, 4: 371-405. https://doi.org/10.1080/233 28940.2017.1377812

Nover, L., Bharti, K., Doring, P., Mishra, S.K., Ganguli, A., Scharf, K.D., 2001. Arabidopsis and the heat stress transcription factor world: how many heat stress transcription factors do we need? Cell Stress Chaperones, 6: 177-189. 
Pandey, P., Irulappan, V., Bagavathiannan, M.V., SenthilKuMAR, M., 2017. Impact of combined abiotic and biotic stresses on plant growth and avenues for crop improvement by exploiting physio-morphological traits. Frontiers in Plant Science, 8: 1-15. https://doi.org/10.3389/ fpls.2017.00537

Pereira, A., 2016, Plant abiotic stress challenges from the changing environment. Frontiers in Plant Science, 7: 2013-2015. https://doi.org/10.3389/fpls.2016.01123

Rastogi, S., Shah, S., Kumar, R., Vashisth, D., Akhtar, M. Q., Kumar, A., Shasany, A. K., 2019. Ocimum metabolomics in response to abiotic stresses: cold, flood, drought and salinity. PLoS ONE, 14: 1-26. https://doi. org/10.1371/journal.pone.0210903

Reynolds-Henne, C.E., Langenegger, A., Mani, J., Schenk, N., Zumsteg, A., Feller, U., 2010. Interactions between temperature, drought and stomatal opening in legumes. Environmental and Experimental Botany, 68 37-43.

Schoots, M. H., Gordijn, S. J., Scherjon, S. A., Van Goor, H., Hillebrands, J. L., 2018. Oxidative stress in placental pathology. Placenta, 69: 153-161. https://doi. org/10.1016/j.placenta.2018.03.003.

Sergiev, I., Alexieva, V., Karanov, E., 1997. Effect of spermine, atrazine and combination between them on some endogenous protective systems and stress markers in plants Proceedings of the Bulgarian Academy of Sciences, 51: 121-124.

Shah, S.H., Houborg, R., McCabe, M.F., 2017. Response of chlorophyll, carotenoid and SPAD-502 measurement to salinity and nutrient stress in wheat (Triticum aestivum L.). Agronomy, 7: 1-20. https://doi.org/10.3390/agronomy7030061

Shalaby, O.A.E., 2018. Alleviation of salinity stress in red cabbage plants by urea and sulfur applications and sulfur applications. Journal of Plant Nutrition, 41 (12): $1597-$
1603. https://doi.org/10.1080/01904167.2018.1462387

Shanahan, J.F., Edwards, I.B., Quick, J.S., 1990. Membrane thermostability and heat tolerance of spring wheat. Crop Science, 30: 247-251.

ShAREEF, H.J., 2019. Salicylic acid and potassium promote flowering through modulating the hormonal levels and protein pattern of Date palm Phoenix dactylifera L. Sayer offshoots. Acta Agriculturae Slovenica, 114: 231-238. https://doi.org/10.14720/aas.2019.114.2.8

Stewart, R.C., Bewley J.D., 1980. Lipid peroxidation associated with accelerated aging of soybean axes. Plant Physiology, 65: 245-248.

TANG, Y., Wang, L., Ma, C., LiU, J., Liu, B., Li, H., 2011. The use of HPLC in determination of endogenous hormones in anthers of bitter melon. Journal of Life Sciences, 5: 139-142.

Urban, L., Aarrouf, J., Bidel, L.P.R., 2017. Assessing the effects of water deficit on photosynthesis using parameters derived from measurements of leaf gas exchange and of chlorophyll a fluorescence, 8 : 1-18. https://doi. org/10.3389/fpls.2017.02068

Watkins, J. M., Chapman, J. M., Muday, G. K., 2017. Abscisic acid-induced reactive oxygen species are modulated by flavonols to control stomata aperture. Plant Physiology, 175: 1807-1825. https://doi.org/10.1104/pp.17.01010

Xu, Z., JiAng, Y., ZHou, G., 2015. Response and adaptation of photosynthesis, respiration, and antioxidant systems to elevated $\mathrm{CO} 2$ with environmental stress in plants. Frontiers in Plant Science, 6: 1-17. https://doi.org/10.3389/ fpls.2015.00701

Zandalinas, S.I., Rivero, R.M., Martínez, V., GómeZ-CADenas, A. Arbona, V., 2016. Tolerance of citrus plants to the combination of high temperatures and drought is associated to the increase in transpiration modulated by a reduction in abscisic acid levels. BMC Plant Biology, 16: $1-16$. 